\title{
Müşteri Değeri, Müşteri Tatmini ve Marka Sadakati: Üniversite Sosyal Tesisleri Üzerine Bir Araştırma
}

\author{
Customer Value, Customer Satisfaction and Brand Loyalty A Research on \\ University Leisure Centres
}

\author{
Yrd. Doç. Dr. İbrahim ÇETINTÜRK \\ Çankırı Karatekin Üniversitesi \\ İktisadi ve İdari Bilimler Fakültesi \\ E-posta: icetinturk32@gmail.com \\ Orcid Id:0000-0002-9078-7606
}

\begin{abstract}
Öz
Araştırmanın önerilen kavramsal modelinde, bağımsız değişkenlerden müşteri değeri, bağımlı değişkenlerden müşteri tatmini ve marka sadakati yer almaktadır. Araştırmanın iki farklı amacı bulunmaktadır. Araştırmanın öncelikle amacı, müşteri değeri ve müşteri değerini oluşturan alt faktörlerin müşteri tatmini ve marka sadakati üzerindeki etkisini incelemektir. Sonraki aşamada ise, müşteri tatmininin marka sadakati üzerindeki etkisini değerlendirmektir. Bu çalışma, Süleyman Demirel Üniversitesi Sosyal Tesislerinde konaklama yapan müşterilere uygulanmıştır. Sosyal tesislerde konaklama yapan 270 müşteri anket formuna cevap vermiştir. Araştırma sonuçlarına göre alanyazını destekleyen şekilde müşteri değeri ile müşteri tatmini ve marka sadakati arasında ve müşteri tatmini ile marka sadakati arasında güçlü bir ilişki tespit edilmiştir. Ayrıca kalite itibarının müşteri tatmini ve marka sadakati üzerinde en fazla etkiye sahip olan müşteri değeri faktörü olduğu tespit edilmiştir.
\end{abstract}

Anahtar Kelimeler: Müşteri değeri, müşteri tatmini, marka sadakati, otel.

\begin{abstract}
The proposed conceptual model of the research includes customer value among the independent variables and customer satisfaction and brand loyalty among the dependent variables. The research has two different purposes. The first purpose is to analyze the impact of customer value and sub-factors composing the customer value on customer satisfaction and brand loyalty. The next purpose is to evaluate the impact of customer satisfaction on brand loyalty. This study was carried out with customers who stayed at University Leisure Centres of Süleyman Demirel University. 270 customers staying at the University Leisure Centres responded to the survey form. According to the research results, a strong relationship between customer valuecustomer satisfaction and brand loyalty and between brand loyalty and customer satisfaction is determined, which supports the literature. In addition, it is determined that quality reputation is the customer value factor which has the biggest impact on customer satisfaction and brand loyalty.
\end{abstract}

Key Words: Customer value, customer satisfaction, brand loyalty, hotel. 


\section{Giriş}

Günümüzde ulusal ve uluslararası ölçekte milyonlarca turisti ağırlayan turizm sektörü ülkelerin ekonomik, sosyal, kültürel gelişiminde önemli rol oynamaktadır. Birleşmiş Milletler Dünya Turizm Örgütü'nün istatistik verilerine göre 2015 yılında dünya çapında turizm hareketine katılan kişi sayısı 1 milyar 184 milyona ulaşmış olup, uluslararası turizm gelirlerinin miktarı 1.260 milyar dolar olarak gerçekleşmiştir (Unwto, 2016:2). Turizm gelirleri Türkiye'nin gayri safi milli hasılasında da (GSMH) önemli bir yer tutmaktadır $^{1}$. Bu nedenle özellikle son 20 yılda dış politikanın belirlenmesinde turizm gelirlerinin artırılması önem arz etmektedir (Akman, 2016:712-732).

Küresel rekabet ortamında, müşteri zevk ve tercihleri sürekli olarak değişmekte ve farklılaşmaktadır. Ürün odaklı hizmet anlayışı yerini müşteri odaklı hizmet anlayışına bırakmıştır. Müşteri taleplerinde ve eğilimlerinde yaşanan değişim ve ekonomide ve endüstrilerde yavaş büyüme birçok organizasyonun müşteri odaklı stratejiler uygulamasına zorunlu hale getirmektedir (Woodruff, 1997:139). Müşteri odaklı stratejiler, öncelikle müşterilerin beklentilerinin anlaşılması, ürünlerin/hizmetlerin maliyet/fayda analizinin yapılması, üst düzeyde değerin tasarlanması ve müşterilere sunulması ile mümkündür.

Müşteri değeri, günümüzün en temel pazarlama stratejilerinden birini oluşturmaktadır. Müşteri değeri, müşterinin satın aldığı ürün/hizmet ile parasal değeri kıyaslaması sonucunda zihninde oluşan duygusal bir süreci ifade etmektedir. Müşteriler kendilerine en yüksek değeri sunan işletmelerin ürün ve hizmetlerini satın almaktadırlar. İşletmeler ise sunmuş oldukları temel ürün ya da hizmetlere daha çok değer ekleyerek müşteri tatmini oluşturmaya çalışmaktadırlar. Müşteri tatmini, ürün ve hizmetin satın alınması ve kullanılması sonucunda oluşan ve müşterinin daha sonraki satın alma tercihlerini etkileyen bir tepkidir (Uzkurt, 2007; Güler, 2009). Ürün ve hizmeti satın alma sonrası oluşan müşteri tatmini müşterilerin sonraki satın alma davranışlarına yansıyacaktır. Bu durum müşterilerde davranışsal ve/veya tutumsal marka sadakatinin oluşmasında önem arz etmektedir.

Bir müşterinin değer algısı diğer müşteriye göre farklılaşabilmektedir. Müşteriler için ürün ve hizmetlerin fiyatı, kalite itibarı ve prestiji (Nasution ve Mavondo, 2008) bir değer unsuru olarak değerlendirilmektedir. Ürün ve hizmetlerin fiyatını en önemli değer unsuru olarak değerlendiren müşteriler düşük fiyatlı bir konaklama işletmesini tercih etmektedirler. Konaklama işletmeleri yöneticilerinin müşteriler tarafından değer verilen unsurları tespit etmesi ve bu unsurlarına yönelik stratejiler belirlemesi işletmeye rekabetçi üstünlük sağlayacaktır.

Iş̧letmeler açısından müşteri değeri, toplam müşteri değeri ve toplam müşteri maliyeti arasındaki farktır. Toplam müşteri değeri toplam ürün değeri, hizmet değeri, personel değeri ve imaj değerinden oluşmaktadır (Yamamoto, 2007:3, Erişim tarihi: 01.06.2016). İşletmeler için değer, tek bir değer unsur yerine müşteriler tarafından algılanan bütün değer unsurlarının kombinasyonudur. Çünkü işletmenin her bir müşteriyi bir değer unsuru olarak görmesi ve ürünlerini/hizmetlerini bu perspektifte tasarlaması gerekmektedir.

Araştırmada müşteri değeri müşteri perspektifi (Patterson ve Spreng 1997; Sanchez ve arkadaşları 2005; Nasution ve Mavondo 2008) ile değerlendirilmiştir.

\footnotetext{
12015 yılında turizm gelirlerinin GSMH'ye toplam katkısı \%12,9 olarak gerçekleşmiştir (World Travel \& Tourism Council, 2016:1).
} 
Araştırmanın iki farklı amacı bulunmaktadır. İlk olarak müşteri değeri ve müşteri değerini oluşturan alt faktörlerin müşteri tatmini ve marka sadakati üzerindeki etkisini incelemektir. İkinci olarak ise, müşteri tatmininin marka sadakati üzerindeki etkisi değerlendirmektir.

\section{Kavramsal Çerçeve}

Alanyazında bilim adamları tarafından değer kavramı için çeşitli sınıflandırmalar yapılmıştır. Sanchez ve diğerlerine (2005:396) göre değer müşteriler, kültürler ve zamanlar arasında değişen subjektif, dinamik ve değişken bir yapıya sahiptir. Müşterinin ürünü/hizmeti satın alma öncesinde, kullanımı sırasında ve satın alma sonrasında yaşadığı deneyimi içermektedir. Diğer bir sınıflandırmada Zeithaml'a göre (1988) değer, müşterilerin bakış açısıyla dört farklı grupta ele alınmıştır: (1) Değer düşük fiyattır. (2) Değer, müşterinin istediği herhangi bir üründür. Müşterinin üründen elde ettikleri yararlar değerin en önemli bileşenini oluşturmaktadır. (3) Değer, müşterinin ödediği para karşılığında elde ettiği kalitedir. Değer, kalite ile fiyat arasında gerçekleşen değiş-tokuştur. (4) Değer, müşterinin verdiği şey karşılığında aldığı şeydir. Değer, vermek bileşeni ile olduğu kadar almak bileşeni ile ilgilidir. Flint ve arkadaşlarına göre (1997) değer üç farklı sınıfta değerlendirilmiştir. Bu sınıflandırma, 'değer, arzulanan değer ve değer yargısı'ndan oluşmaktadır. Arora ve Singer (2006: 93) değer kavramının endüstriler/sektörler arasında değişebileceğini ve şunları içerdiğini ifade etmişlerdir: 'Müşteriye ekstra birşeyler sağlamak, müşterilerin ihtiyaçlarını tatmin etmek ve beklentilerini karşılamak, müşterilere düşük fiyattan veya temel ürünlerden daha fazlasını sunmak, rakiplerin ürünlerinden daha üstün ürünler sunmak ve yüksek kaliteli ürünler sunmak.'

Değere ilişkin disiplinlerarası yaklaşım Tablo 1'de yer almaktadır. Değer kavramı bilim adamları tarafından farklı gruplarda ele alınmıştır. Sheth ve arkadaşları (1991 a,b) değerin boyutlarını sosyal değer, duygusal değer, fonksiyonel değer, epistemik değer, koşullu değer olmak üzere beş farklı sınıfta değerlendirmişlerdir. Grönroos (1997) değer kavramını, bilişsel ve duygusal (psikolojik) olarak iki farklı perspektifte değerlendirmiştir. De Ruyter ve arkadaşları (1997) değeri, duygusal boyut veya gerçek değer, fonksiyonel boyut veya geçici değerin yanısıra mantıksal boyut ile değerlendirmişlerdir. Sweeney ve Soutar (2001)değeri, fonksiyonel boyut (ekonomik ve kalite), duygusal boyut ve sosyal boyut ile ele almışlardır. Wang ve arkadaşları (2004) değerin boyutlarını; fonksiyonel değer, sosyal değer, duygusal değer ve algılanan fedakârlık olarak sınıflandırılmıştır. Sanchez ve arkadaşları (2005) turizmde değer kavramını altı farklı boyutta ele almışlardır. Bunlar; seyahat acentesinin fonksiyonel değeri, seyahat acentesinde iletişim kuran personelin fonksiyonel değeri, satın alınan turizm paketinin fonksiyonel değeri, fonksiyonel değer fiyatı, duygusal değer ve toplumsal değerden oluşmaktadır. Fonksiyonel boyut, bireyler tarafından üretilen rasyonel ve ekonomik değerlendirmeyi ifade etmektedir. Ürün ve hizmetin kalitesi bu boyutun bir parçasını oluşturmaktadır. Duygusal boyut ise, müşterilerin ürünlere/hizmetlere karşı his ve duygularını ifade etmektedir. 
Tablo 1: Değere İlişkin Disiplinlerarası Yaklaşım

\begin{tabular}{|l|l|l|l|}
\hline Yazar & \multicolumn{1}{|c|}{ Boyutlar } & Yazar & \multicolumn{1}{c|}{ Boyutlar } \\
\hline $\begin{array}{l}\text { Sheth ve } \\
\text { arkadaşları } \\
\text { (1991a, b) }\end{array}$ & $\begin{array}{l}\text { Sosyal değer } \\
\text { Duygusal değer } \\
\text { Fonksiyonel değer } \\
\text { Epistemik değer } \\
\text { Koşullu değer }\end{array}$ & $\begin{array}{l}\text { Sweeney ve } \\
\text { arkadaşları (1999) }\end{array}$ & $\begin{array}{l}\text { Sosyal değer (uygunluk) } \\
\text { Duygusal değer } \\
\text { Fonksiyonel değer (fiyat/para için } \\
\text { değer) }\end{array}$ \\
$\begin{array}{l}\text { Fonksiyonel değer } \\
\text { (performans/kalite) } \\
\text { Fonksiyonel değer (çok yönlülük) }\end{array}$ \\
$\begin{array}{l}\text { Groth } \\
\text { (1995a,b) }\end{array}$ & $\begin{array}{l}\text { Bilişsel: Algılanan fayda } \\
\text { Psikolojik } \\
\text { Iç } \\
\text { Dış }\end{array}$ & $\begin{array}{l}\text { Wang ve arkadaşları } \\
\text { (2004) }\end{array}$ & $\begin{array}{l}\text { Fonksiyonel değer } \\
\text { Sosyal değer } \\
\text { Duygusal değer } \\
\text { Algılanan fedakârlık }\end{array}$ \\
\hline $\begin{array}{l}\text { Grönroos } \\
\text { (1997) }\end{array}$ & $\begin{array}{l}\text { Bilişsel } \\
\text { Duygusal (psikolojik) }\end{array}$ & $\begin{array}{l}\text { Sanchez ve } \\
\text { arkadaşları (2005) }\end{array}$ & $\begin{array}{l}\text { Fonksiyonel değer (seyahat } \\
\text { acentesi-personel-turizm paketi) } \\
\text { Fonksiyonel değer fiyatı } \\
\text { Duygusal değer } \\
\text { Toplumsal değer }\end{array}$ \\
\hline $\begin{array}{l}\text { De Ruyter ve } \\
\text { arkadaşları } \\
\text { (1997) }\end{array}$ & $\begin{array}{l}\text { Duygusal boyut veya } \\
\text { gerçek değer }\end{array}$ & $\begin{array}{l}\text { Fonksiyonel boyut veya } \\
\text { geçici değer } \\
\text { Mantıksal boyut }\end{array}$ & Nasution ve \\
Mavondo (2008) & $\begin{array}{l}\text { Kalite itibarı } \\
\text { Parasal değer } \\
\text { Prestij }\end{array}$ \\
\hline
\end{tabular}

Kaynak: Sanchez ve arkadaşları (2005:396); Woodruff (1997)

Slater ve Narver'a göre (2000) müşteri değeri, müşteriye sunulan ürünün/hizmetin faydalarının toplam maliyetleri aşması durumunu açıklamaktadır. Woodruff'a göre $(1997: 14,141)$ müşteri değeri, müşterilerin ürün ve hizmetlerden beklentilerini, inançlarını, satın alma ve kullanım sonrası elde ettiklerini (kalite, fayda, değer) açıklamaktadır. Zeithaml'a göre (1988) müşteri değeri, müşterinin katlandıkları (harcama, zaman, çaba) ile elde ettiklerinin (değer, yüksek kalite, yarar, kolaylık, uygunluk) genel bir değerlendirmesidir. Müşterinin katlandığı maliyetler karşılığında elde ettiği faydayı ifade etmektedir. Deng ve arkadaşlarına göre (2013) müşteri değeri, algılanan maliyet ve kalite arasındaki değiş tokuşa dayanmaktadır. Uzkurt (2007) müşteri değeri kavramı ile ilgili özellikleri şu şekilde özetlemiştir:

- Müşteri değeri, müşteri tarafından algılanan değerdir.

- Müşteri değeri, toplam fayda ile toplam maliyetlerin müşteriler tarafından oransal olarak algılanmasıdır.

- Müşteri değerinin artırılmasında faydaların artırılması kadar maliyetlerin de minimize edilmesi önemlidir.

- Müşterilerin değer algısı subjektiftir.

- Müşteri değerinin oluşmasında ürün ve hizmetin özellikleri ile birlikte sunumu ve müşteri iliş̧ileri önemli rol oynar.

Müşteri değeri ve müşteri tatmini arasındaki kavramsal farklılıkların değerlendirilmesi Tablo 2'de yer almaktadır (Eggert ve Ulaga 2002): Müşteri değeri satın alma öncesi ve sonrasında ortaya çıkan perspektifle değerlendirilirken, müşteri tatmini sadece satın alma sonrası ortaya çıkan perspektifle değerlendirilmiştir. Müşteri değeri, müşterilerin kendilerine sunulanları nasıl değerlendirmesi gerektiği ile ilgili olduğu için firmanın müşteri intiyaçlarını en iyi şekilde karşılayacağı stratejik bir yaklaşımı zorunlu kılar. Ancak müşteri tatmini, hizmet sunan tarafın hizmeti ne kadar iyi sunduğuyla ilgili olduğu için taktiksel bir odaklanmayı gerektirir. Müşteri tatmini, mevcut müşterilerin değerlendirmesiyle gerçekleşirken, müşteri değeri geçmiş, mevcut ve gelecekteki potansiyel müşterilerin değerlendirmesiyle gerçekleşen bir süreçtir. Müşteri 
tatmini, firma tarafından sunulanların değerlendirilmesi sonucu ortaya çıkarken, müşteri değeri aynı zamanda rakip ürün ve hizmetlerin de dikkate alınarak değerlendirilmesiyle ortaya çıkan bir yargılamadır (Uzkurt, 2007).

Tablo 2: Tatmin ve Değer Arasındaki Kavramsal Farklılık

\begin{tabular}{|l|l|}
\hline Müşteri tatmini & Algılanan müşteri değeri \\
\hline Duygusal yapı & Bilişsel yapı \\
\hline Satın alma sonrası perspektif & Satın alma öncesi ve sonrası perspektif \\
\hline Taktiksel oryantasyon & Stratejik oryantasyon \\
\hline Güncel müşteriler & Güncel ve potansiyel müşteriler \\
\hline Tedarikçilerin teklifleri & Tedarikçilerin ve rakiplerin teklifleri \\
\hline Kaynak: Eggert ve Ulaga, 2002 &
\end{tabular}

Oliver'e göre (1997) tatmin 'ürün ve hizmetin özelliği veya ürün ve hizmetin kendisi ile ilgili müşterinin memnun olmasına olanak sağlamaktadır'. Tatmin tüketicilerin ürün ve hizmetlerden elde ettiği standart bir hoşnutluğun ifadesidir. Müşteri tatmini ise, bazı intiyaçları, arzuları ve amaçları yerine getirilen tüketicilerin memnun olmasını ifade etmektedir. Diğer bir tanımda müşteri tatmini, müşterinin ürünü/hizmeti satın alma sonrası tüm marka deneyimine genel duygusal bir tepkisi olarak ifade edilmektedir (Nam ve arkadaşları 2011). Rodriguez del Bosque ve San Martin'e göre (2008) müşteri tatmini, sadece bilişsel değil aynı zamanda duygusal bir süreçtir (Nam ve arkadaşları 2011). Oh'a göre (2000) müşteri tatmini, algılanan müşteri değerinin potansiyel bir sonucudur. Neal'a göre (1999) müşteri tatmini, müşterilerin ürün ve hizmetlerden beklentileri ile işletme performansını algılamaları arasındaki etkileşimin sonucu oluşan tutumu ifade etmektedir. Kandampully ve Suhartanto'ya göre (2000) müşteri tatmini ise, bir firmanın pazarlama faaliyetlerinde en önemli sonuç olarak değerlendirilmektedir.

Ren ve arkadaşları (2016) müşteri tatminine neden olan kaynakları dört boyutta değerlendirmişlerdir: Bu boyutlar; 'maddi ve duyusal deneyim, personel performansı, estetik algı ve konum'dan oluşmaktadır. Gu ve Ryan (2008) konaklama işletmelerinde müşteri tatminini pozitif yönde etkileyen yedi faktörden bahsetmişlerdir: Bu faktörler; 'yatak konforu, banyonun temizliği, odanın büyüklüğü, etkinlikler, konum ve erişilebilirlik, yiyecek ve içecek kalitesi, yardımcı hizmetler ve personelin performansından oluşmaktadır.

Marka, satıcıların veya bir grup satıcının ürün ve hizmetleri tanımlamasına ve rakiplerin ürün ve hizmetlerden farklılaştırmasına yönelik ayırt edici bir isim ve/veya semboldür (örnek; Hilton, Mariott). Birçok otel ve restoran zinciri özel müşteri gruplarının beklentilerini karşılamak için araştırma yapmaktadır. Bu işletmeler belirli bir alanda iz bırakmak (örnek, Ritz Carlton lüks bir otel) ve ürün/hizmet üzerinde etkisini (örnek, Disney'in yaratıcı tema park konsepti) hissettirmek istemektedir (Aaker, 1991; Tepeci, 1999). Birçok organizasyonun amacı ise pazarda güçlü bir marka oluşturmaktır. Çünkü bu durum firmaya bir takım yararlar sağlamaktadır. Bunlar içerisinde, rekabetçi pazarlama faaliyetleri, pazarda daha az kırılganlık, daha büyük marjlar ve daha fazla oranda aracılarla işbirliği yer almaktadır (Ballester ve Aleman 2005).

Sadakat, farklı zaman dilimlerindeki müşteri tatmininin bir araya gelmesi ile veya kümülatif tatmin ile oluşmaktadır. Sadakat, son derece içten yapılan tekrar satın alma davranışını veya ürünün/hizmetin tutarlı bir şekilde müşterisi olma eğilimini ifade etmektedir (Oliver 1997). Sadakat davranışsal sadakat, tutumsal sadakat ve karma yaklaşım olmak üzere üç farklı boyutta incelenmektedir. Tekrar eden satın alma 
davranışları sadakatin davranışsal boyutunu oluşturmaktadır. Tutumsal sadakat, satınalma davranışı tekrarlanmasa bile tüketicinin ürün/hizmet hakkında olumlu konuşması, ürünü/hizmeti başkalarına tavsiyelerde bulunması olarak ifade edilmektedir. Karma yaklaşım ise, sadakatin hem davranışsal hem de tutumsal boyutunu birlikte incelemektedir (Meyer ve Allen, 1997; Bowen ve Chen, 2001: 213; Huang ve Zhang, 2008:103 ).

Marka sadakati, hem davranış ve hem de tutumların bir fonksiyonudur. Konaklama işletmelerinde sadık müşterilere hizmet sunumunun gerçekleştirilmesi daha kolaydır ve sadık müşteriler işletmeye daha fazla karlılık sağlamaktadır. Reichheld (1996) marka sadakatinin avantajlarını şu şekilde ifade etmektedir (Tepeci, 1999):

- Sürdürülebilir karlııı,

- Maliyetlerinin düşürülmesi,

- Müşteri başına elde edilen gelirlerde artış sağlanması,

- Müşteri potansiyelinin artırılması,

- Ürün/hizmet fiyatlarının artırılması,

- Rekabet üstünlüğü sağlanması.

Konaklama işletmeleri markalarına sadık müşteri sayılarını artırarak pazar paylarını ve büyüme oranlarını daha üst noktalara çekebilirler. Bu yaklaşım, diğer pazarlama faaliyetlerine göre (fiyat indirimi, promosyonlar, vd.) daha karlı bir yöntemdir (Tepeci, 1999).

Turizm işletmelerinde müşteri değeri konusunda yapılan çok sayıda araştırma bulunmaktadır. Araştırmalar arasında Wang ve arkadaşlarının (2004) yaptıkları araştırmada, müşteri değeri ve müşteri ilişkileri yönetimi performansı için bütüncül bir çerçeve geliştirilmiştir. Sanchez ve arkadaşlarının (2005) yaptıkları araştırmada, turizmde algılanan değer konsepti oluşturulması ve genel algılanan değer ölçeği geliştirilmesi amaçlanmıştır. Araştırma sonucunda, bir turistin satın alma deneyiminin tüketim deneyiminden ayrı olarak değerlendirilemeyeceği ve bu deneyimlerin bir bütün olarak ele alınması gerektiği ifade edilmiştir. Nasution ve Mavondo (2008) otel işletmeleri üzerine yaptıkları araştırmada, müşteri değeri hizmet sağlayıcılar ve müşteriler olmak üzere iki farklı perspektif ile incelenmiştir. Araştırma sonuçlarına göre, yöneticilerin müşteri değer algısı ile müşterilerin değer algısı arasında fark bulunmaktadır. Araştırmada otel işletmelerinin müşterilerle ilişkili ve onları anlamaya yönelik faaliyetlere yatırım yapmaları gerektiği ifade edilmiştir.

Gibson (2005) konaklama işletmeleri üzerine yaptığı bir çalışmada, memnun müşterilerin ürün ve hizmetleri tekrar talep edeceklerine ve ailelerine ve arkadaşlarına deneyimlerine ilişkin olumlu geri dönüşüm sağlayacaklarını ifade etmiştir. O'Fallon ve Rutherford (2011) konaklama işletmelerinde müşteri tatmininin otel skor kart (karne) ile ölçüldüğünü ifade etmiştir. Otel skor kart özellikle müşterilerin oteli tekrar tercih etmeleri ve çevrelerine tavsiyelerde bulunma durumlarını ölçmek amacıyla kullanılmaktadır. Otelin hesap tablosu otelin finansal durumu hakkında bilgi sağlarken, müşteri tatminini ölçen skor kart otelin itibar durumunu göstermektedir.

Müşteri değeri ile müşteri tatmini kavramları birbiriyle bağlantılı bir şekilde konumlandırılmıştır (Güler, 2009). Ürün ve hizmetlerden üstün değer ile müşteri tatmini arasında doğrudan ilişki bulunmaktadır. Bitner (1990) yaptığı araştırmada, müşteri tatmininin algılanan kalitenin aracılık rolü ile marka sadakati üzerinde dolaylı etkisinin olduğunu tespit etmiştir. Wang ve arkadaşlarının (2004) yaptıkları araştırmada müşteri değerinin her bir boyutunun marka sadakati üzerinde doğrudan etkisinin olmadığı, 
müşteri tatmininin aracılık rolü ile dolaylı etkisinin olduğu saptanmıştır. Cronin ve arkadaşları (2000) yaptıkları araştırmada algılanan değer ve müşteri tatmini arasında pozitif bir ilişki tespit etmişlerdir. Fornell ve arkadaşları (1996) yaptıkları araştırmada, algılanan müşteri değerinin müşteri tatmini üzerinde pozitif bir etkisi olduğunu tespit etmişlerdir.

Alanyazın çalışmalarında müşteri tatmininin marka sadakati üzerinde pozitif ve doğrudan etkisinin olduğu saptanmıştır. Shoemaker ve Lewis (1999) yaptıkları araştırmada, müşteri tatmini ve marka sadakati arasında zayıf bir ilişki tespit etmişlerdir (Back ve Parks, 2003). Kandampully ve Suhartanto'nun (2000) Yeni Zellanda'da faaliyet gösteren otel işletmelerinde yaptıkları araştırma sonuçlarına göre, müşteri tatmini ile müşteri sadakati arasında pozitif yönde bir ilişki vardır. Müşterilerin kat hizmetleri bölümünden elde ettikleri müşteri tatmininin resepsiyon, yiyecek içecek bölümlerine ve otel fiyatına göre daha önemli olduğu saptanmıştır. Ayrıca müşteri tatmininin müşterilerin aynı oteli tekrar tercih etmelerinde, başkalarına tavsiyede bulunmalarında etkili olduğu tespit edilmiştir. Cronin ve Taylor (1992) hizmet sektöründe yaptıkları çalışmada, müşteri tatmininin müşterinin tekrar satın alma isteğinde önemli etkisi olduğunu saptamıştır. McAlexander ve arkadaşlarının (1994) sağlık sektöründe yaptığı araştırmada, hasta tatmini tekrar satın alma isteğinde önemli bir etkiye sahip olduğu tespit edilmiştir (Kandampully ve Suhartanto, 2000). Back ve Parks'ın (2003) yaptıkları araştırma, hizmet sektöründe müşteri tatmini ve marka sadakati arasındaki pozitif ilişkiyi desteklemektedir. Rust ve Zahorik (1993) bankacılık ve otelcilik sektörlerinde yaptıkları araştırmada müşteri tatmini ve marka sadakati arasında pozitif bir ilişkiden söz etmiştir. McDougall ve Levesque (1994) farklı sektörlerde yaptıkları araştırmada müşteri tatmininin marka sadakati üzerinde pozitif bir etkiye sahip olduğu saptanmıştır (Tepeci, 1999). Huang ve Zhang (2008) yaptıkları araştırmada müşteri değeri ile marka sadakati arasındaki ilişkiyi çok boyutlu değerlendirmişlerdir. Yazarlar müşteri değerinin marka sadakati üzerindeki etkisini kavramsal bir modelle incelemişlerdir. Araştırma sonuçlarına göre, fonksiyonel değer ve sembolik değerin tutumsal ve davranışsal sadakat üzerinde önemli etkisinin olduğu, deneyimsel değer ve algılanan fiyatın davranışsal sadakat üzerinde dolaylı etkisinin olduğu tespit edilmiştir.

\section{Araştırmanın Yöntemi}

\subsection{Araştırmanın Amacı ve Önemi}

Nasution ve Mavondo (2008) yaptıkları araştırmada müşteri değerini hizmet sağlayıcılar ve müşteriler olmak üzere iki farklı perspektif ile incelemişlerdir. Müşteri değerini oluşturan bileşenler kalite itibarı, parasal değer ve prestijden oluşmaktadır. Kalite itibarı, işletmenin hizmet/ürün kalitesini ve duygusal değer anlayışını ifade etmektedir. Parasal değer; yararlar, fedakârlıklar ve maliyetlerin karşılaştırılmasıdır. Prestij, bir işletmeden faydalanma veya ürün/hizmeti satın alma karşılığında elde edeceği sosyal değeri ifade etmektedir.

Öncelikle araştırmanın amacı, müşteri değeri ve müşteri değerini oluşturan alt faktörlerin müşteri tatmini ve marka sadakati üzerindeki etkisini incelemektir. Sonraki aşamada ise müşteri tatmininin marka sadakati üzerindeki etkisi değerlendirilmiştir.

Çalışmada Nasution ve Mavondo'nun (2008) müşteri değeri (kalite itibarı, parasal değer ve prestij) ölçeğinden faydalanılmıştır. Nasution ve Mavondo (2008) müşteri değeri ölçeğini, Sweeney ve Soutar'ın (2001) ve Petrick'in (2002) araştırmalarından esinlenerek oluşturmuştur. Müşteri sadakati ve marka sadakatinin 
anket sorularının oluşturulmasında Wang ve arkadaşları (2004) ile Onaran ve arkadaşlarının (2013) ölçeklerinden faydalanılmıştır.

Bu çalışma, Süleyman Demirel Üniversitesi Sosyal Tesislerinde (Konukevi, Mavigöl Otel, Çiftçi Eğitim Merkezi) konaklama yapan müşterilere uygulanmıştır. Araştırmanın örneklemini, tesadüfi örnekleme yöntemiyle seçilen ve konaklama yapan 270 müşteri oluşturmaktadır. Elde edilen bulgular ulaşılan örneklemi temsil etmektedir. Araştırma bulgularının evrene genellenemeyeceği göz önünde bulundurulmalıdır.

Veriler, anket tekniği (yüz yüze görüşme) kullanılarak elde edilmiştir. Anketler Mart-Nisan 2015 tarih aralığında uygulanmıştır. Anketler, otel müşterilerine gönüllülük esasına göre kendilerinden izin alınarak gerçekleştirilmiştir. Araştırmada elde edilen veriler SPSS (Statistical Package for Social Sciences) programı kullanılarak analiz edilmiştir. Araştırmada kullanılan verilerin normal dağılım gösterip göstermediğini ölçmek amacıyla Kolmogorov-Smirnov testi uygulanmıştır. Test sonucunda çalışmada kullanılan verilerin anlamlılık değerlerinin tümünün, 05 'den büyük olduğu ve normal dağılım gösterdiği tespit edilmiştir.

Çalışmada, öncelikle verilerin faktör yükleri belirlenmiştir. Araştırmanın bağımlı ve bağımsız değişkenler arasındaki ilişki Pearson Korelasyon testi ile analiz edilmiştir. Bağımlı ve bağımsız değişken arasında doğrusal ilişki olup olmadığını ölçmek için basit regresyon analizi uygulanmıştır. Birden fazla bağımsız değişkenin bir bağımlı değişken üzerindeki etkisini ölçmek için çoklu regresyon analizi kullanılmıştır.

Anket formuna son şeklinin verilmesi amacıyla 50 müşteri, ile pilot araştırma (ön test) yapılmıştır. Pilot araştırmada, anket formunda yer alan soruların anlaşılabilirliğinin ve ölçüm aracının içerik geçerliliğinin de test edilmesine olanak sağlanmıştır. Yapılan pilot uygulamada ölçeğin yapısı, geçerliliği ve güvenilirliği test edilmiştir. İçsel tutarlılık analizi yöntemi olarak Cronbach Alfa katsayısı hesaplanmıştır. Yapılan hesaplamalarda Cronbach Alfa katsayıları; 'müşteri değeri=,871', 'müşteri tatmini=,931', 'müşteri sadakati=,944' olarak hesaplanmıştır. Cronbach Alfa katsayılarının ,70'den büyük olması ölçeğin güvenilirliğinin bir göstergesidir (Kalaycı, 2010).

Çalışmanın kısıtları, araştırmanın bir üniversitenin sosyal tesislerinde gerçekleştirilmesi ve sadece müşteri boyutu ile değerlendirilmesidir.

\subsection{Araştırmanın Kavramsal Modeli Ve Hipotezleri}

Önerilen kavramsal modelde; araştırmanın bağımsız değişkenlerinden müşteri değeri ve araştırmanın bağımlı değişkenlerinden müşteri tatmini ve marka sadakati yer almaktadır. Müşteri değerini oluşturan faktörler kalitenin değeri, parasal değer ve prestijden oluşmaktadır. Öncelikle araştırmada müşteri değeri ve müşteri değerini oluşturan alt faktörlerin müşteri tatmini ve marka sadakati üzerindeki etkisi incelenmiştir. Sonraki aşamada ise müşteri tatmininin marka sadakati üzerindeki etkisi değerlendirilmiştir.

Araştırma modelinde, müşteri değeri (kalite itibarı, parasal değer ve prestij) elde eden turistlerin müşteri tatmini sağlayacakları ve işletmeye sadık müşteriler olacakları öngörülmektedir. 
Şekil 1: Araştırmanın Kavramsal Modeli
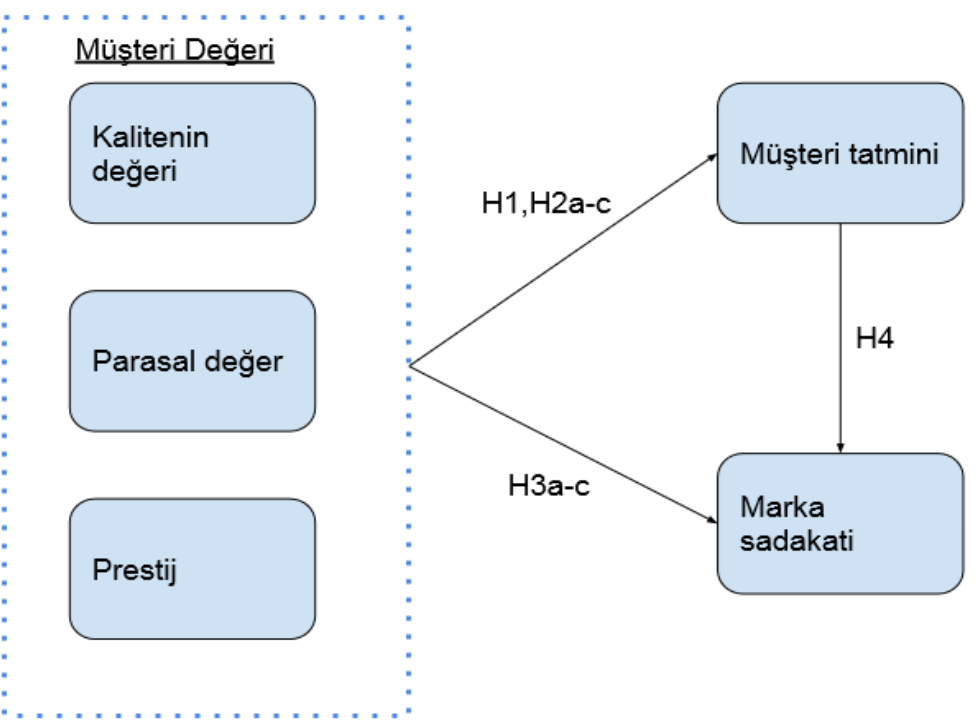

Araştırma hipotezlerinin oluşturulmasında literatür çalışmalarından faydalanılmıştır (Cronin ve Taylor, 1992; Rust ve Zahorik, 1993; McAlexander ve arkadaşları 1994; McDougall ve Levesque, 1994; Neal, 1999; Kandampully ve Suhartanto, 2000; Cronin ve arkadaşları 2000; Sirdeshmukh ve arkadaşları 2002; Back ve Parks, 2003; Wang ve arkadaşları 2004; Uzkurt, 2007; Huang ve Zhang, 2008; Özer ve arkadaşları 2013; Onaran ve arkadaşları 2013).

H1 = Müşteri değeri müşteri tatminini pozitif yönde etkilemektedir.

$\mathrm{H} 2 \mathrm{a}=$ Kalite itibarı müşteri tatminini pozitif yönde etkilemektedir.

$\mathrm{H} 2 \mathrm{~b}=$ Parasal değer müşteri tatminini pozitif yönde etkilemektedir.

$\mathrm{H} 2 \mathrm{c}=$ Prestij müşteri tatminini pozitif yönde etkilemektedir.

$\mathrm{H} 3 \mathrm{a}=$ Kalite itibarı marka sadakatini pozitif yönde etkilemektedir.

$\mathrm{H} 3 \mathrm{~b}=$ Parasal değer marka sadakatini pozitif yönde etkilemektedir.

$\mathrm{H} 3 \mathrm{c}=$ Prestij marka sadakatini pozitif yönde etkilemektedir

H4= Müşteri tatmini marka sadakatini pozitif yönde etkilemektedir.

\section{Araştırmanın Bulguları}

Araştırmanın demografik bulguları Tablo 3'de yer almaktadır. Araştırmaya katılan müşteriler \%43 bayan, \%57 erkek olarak dağılım göstermektedir. Müşterilerin \%45,9'u evli, \%53'ü bekârlardan oluşmaktadır. Müşterilerin büyük bir oranda üniversite mezunu $(\% 76,6)$ oldukları dikkat çekmektedir. Müşterilerin yaşlarına göre dağılımında; \% 55,6'sı 20-34 yaş grubunda, \%31,1'i 35-49 yaş grubunda dağılım göstermektedir. Müşterilerin gelirlerine göre dağılımda ise, \%45,9'u 1000 TL ile 3000 TL arasında gelire sahiptir.

Tablo 3: Demografik Özelliklerin Dağılımı

\begin{tabular}{|l|c|c|}
\hline & Sayı & Yüzde \\
\hline Cinsiyet & 116 & 43,0 \\
\hline Bayan & 154 & 57,0 \\
\hline Erkek & \multicolumn{2}{|l|}{} \\
\hline Medeni Durum & 124 & 45,9 \\
\hline Evli & 143 & 53,0 \\
\hline Bekar & 3 & 1,1 \\
\hline Kayıp veri & \multicolumn{2}{|c|}{} \\
\hline
\end{tabular}


Tablo 3'ün Devamı

\begin{tabular}{|l|c|c|}
\hline Eğitim Düzeyi & 15 & 5,6 \\
\hline İlköğretim & 46 & 17 \\
\hline Lise & 161 & 59,6 \\
\hline Üniversite & 46 & 17,0 \\
\hline Lisansüstü & 2 &, 7 \\
\hline Kayıp veri & 14 & 5,2 \\
\hline Yaş & 150 & 55,6 \\
\hline $15-19$ & 84 & 31,1 \\
\hline $20-34$ & 20 & 7,4 \\
\hline $35-49$ & 2 &, 7 \\
\hline 50 ve üzeri & \multicolumn{2}{|c|}{} \\
\hline Kayıp veri & 55 & 2,4 \\
\hline Gelir & 68 & 25,2 \\
\hline 1000 TL'den az & 56 & 2,7 \\
\hline $1001-2000$ & 87 & 32,2 \\
\hline $2001-3000$ & 4 & 1,5 \\
\hline 3001 TL ve üzeri & \multicolumn{2}{|c|}{} \\
\hline Kayıp veri &
\end{tabular}

Tablo 4'de müşteri değeri değişkenini ölçeğindeki 12 maddenin güvenirliğini hesaplamak için iç tutarlılık katsayısı olan 'Cronbach Alpha' hesaplanmıştır (Cronbach Alpha= ,849). Ölçeğin yapı geçerliliğini ortaya koymak için açıklayıcı (açımlayıcı) faktör analizi yöntemi uygulanmıştır. Barlett testi sonucunda faktör analizine alınan değişkenler arasında ilişki olduğu tespit edilmiştir $(p=, 000<, 05)$. Kaiser-Meyer-Olkin (KMO) testi sonucunda $(\mathrm{KMO}=, 759>, 60)$ örneklem büyüklüğünün faktör analizinin uygulanması için yeterli olduğu tespit edilmiştir. Müşteri değeri ölçeğinin faktör analizi için özdeğeri 1,00 'den büyük faktörlerin değerlendirilmesine, değişkenlerin faktör içerisindeki ağırlığını gösteren faktör yüklerinin yüksek olmasına, aynı değişken için faktör yüklerinin birbirine yakın olmamasına dikkat edilmiştir. Faktör analizi sonucunda, değişkenler toplam açıklanan varyansı \% 75,93 olan üç faktör altında toplanmıştır. 6 . soru analizden çıkartılmıştır.

Tablo 4'de müşteri tatmini değişkenini ölçeğindeki 5 maddenin güvenirliğini hesaplamak için iç tutarlılık katsayısı olan 'Cronbach Alpha' hesaplanmıştır (Cronbach Alpha=,913). Ölçeğin yapı geçerliliğini ortaya koymak için açıklayıcı (açımlayıcı) faktör analizi yöntemi uygulanmıştır. Barlett testi sonucunda, faktör analizine alınan değişkenler arasında ilişki olduğu tespit edilmiştir $(p=, 000<, 05)$. KMO testi sonucunda $(\mathrm{KMO}=, 844>, 60)$ örneklem büyüklüğünün faktör analizinin uygulanması için yeterli olduğu tespit edilmiştir. Müşteri tatmini ölçeğinin faktör analizi için özdeğeri 1,00'den büyük faktörlerin değerlendirilmesine, değişkenlerin faktör içerisindeki ağırlığını gösteren faktör yüklerinin yüksek olmasına, aynı değişken için faktör yüklerinin birbirine yakın olmamasına dikkat edilmiştir. Faktör analizi sonucunda, değişkenler toplam açıklanan varyansı \% 74,03 olan bir faktör altında toplanmıştır.

Tablo 4'de marka sadakati değişkenini ölçeğindeki 3 maddenin güvenirliğini hesaplamak için iç tutarlılık katsayısı olan 'Cronbach Alpha' hesaplanmıştır (Cronbach Alpha=,909). Ölçeğin yapı geçerliliğini ortaya koymak için açıklayıcı (açımlayıcı) faktör analizi yöntemi uygulanmıştır. Barlett testi sonucunda, faktör analizine alınan değişkenler arasında ilişki olduğu tespit edilmiştir $(p=, 000<, 05)$. KMO testi sonucunda $(\mathrm{KMO}=, 705>, 60)$ örneklem büyüklüğünün faktör analizinin uygulanması için yeterli olduğu tespit edilmiştir. Marka sadakati ölçeğinin faktör analizi için özdeğeri 1,00'den büyük faktörlerin değerlendirilmesine, değişkenlerin faktör içerisindeki ağırlığını gösteren faktör yüklerinin yüksek olmasına, aynı değişken için faktör yüklerinin birbirine yakın olmamasına dikkat edilmiştir. Faktör analizi sonucunda, değişkenler toplam açıklanan varyansı \% 84,69 olan bir faktör altında toplanmıştır. 
Tablo 4: Değişkenlere İlişkin Faktör Yükleri

\begin{tabular}{|c|c|c|c|c|}
\hline & $\begin{array}{l}\text { Faktör } \\
\text { Yükleri }\end{array}$ & Öz değer & $\begin{array}{l}\text { Varyans } \\
\text { Açıklama } \\
\text { Oranı (\%) }\end{array}$ & $\begin{array}{l}\text { Kaiser-Meyer- } \\
\text { Olkin (KMO) }\end{array}$ \\
\hline Müşsteri Değeri & & & 75,931 & ,759 \\
\hline Kalitenin değeri & & 4,418 & 31,737 & \\
\hline Otel en üst kalitede hizmet vermektedir & ,891 & & & \\
\hline Otelin hizmet kalitesi sürekli artmaktadır & ,932 & & & \\
\hline Otelin hizmeti çok güvenilirdir & ,859 & & & \\
\hline Otel 'yüksek kaliteli otel' olarak değerlendirilir & ,700 & & & \\
\hline Bu otelde kalmaktan zevk alıyorum & ,652 & & & \\
\hline Parasal değer & & 2,099 & 22,994 & \\
\hline Otel fiyatlarının makul olduğunu düşünüyorum & ,893 & & & \\
\hline Otel fiyat karşılığı değer sunmaktadır & ,900 & & & \\
\hline $\begin{array}{l}\text { Otel rezervasyon sistemi benim için } \\
\text { uygun/kullanışlıdır }\end{array}$ & ,784 & & & \\
\hline Prestij & & 1,836 & 21,200 & \\
\hline Bu otelde konaklama prestij ifade eder & ,911 & & & \\
\hline $\begin{array}{l}\text { Bu otelde konaklamanın bir statü sembolü } \\
\text { olduğunu düşünüyorum }\end{array}$ & 947 & & & \\
\hline $\begin{array}{l}\text { Bu otelde konaklamak sosyal statüme } \\
\text { uygundur }\end{array}$ & 669 & & & \\
\hline Müşteri tatmini & & 3,702 & 74,031 & ,844 \\
\hline Otelin hizmetleri daima beklentilerimi karşılar & ,814 & & & \\
\hline $\begin{array}{l}\text { Diğer otellerde yaşadığım deneyimlere } \\
\text { dayanarak bu otelin hizmetlerinden memnun } \\
\text { kaldım }\end{array}$ & ,877 & & & \\
\hline $\begin{array}{l}\text { Bu otelin sunduğu hizmetler daima beklenen } \\
\text { düzeydedir }\end{array}$ & ,876 & & & \\
\hline $\begin{array}{l}\text { Bu işletmenin sunduğu hizmeti benim için } \\
\text { uygun zamanlarda alabiliyorum }\end{array}$ & ,891 & & & \\
\hline $\begin{array}{l}\text { Bu otelden aldığım hizmet beklentilerimden } \\
\text { fazlasını karşılamıştır }\end{array}$ & ,842 & & & \\
\hline Marka sadakati & & 2,541 & 84,694 & ,705 \\
\hline $\begin{array}{l}\text { Bu işletmeye/markaya kendimi sadık } \\
\text { hissediyorum }\end{array}$ & ,872 & & & \\
\hline Bu işletme/marka benim ilk tercihimdir & ,953 & & & \\
\hline $\begin{array}{l}\text { Daha fazla teklifler sunulsa da diğer } \\
\text { markaları/işletmeleri tercih etmeyeceğim. }\end{array}$ & ,934 & & & \\
\hline
\end{tabular}

Bartlett's Test of Sphericity $\mathrm{p}<, 05$ (sig.=,000)

Analiz sonuçlarına göre (Tablo 5); müşteri değeri ve müşteri tatmini $(r=, 698$; $p=, 000<, 05)$, müşteri değeri ve marka sadakati $(r=, 567 ; p=, 000<, 05)$, müşteri tatmini ve marka sadakati $(r=, 672 ; p=, 000<, 05)$ arasında pozitif yönlü ve anlamlı bir ilişki tespit edilmiştir.

Araştırmada müşteri tatmini ile en fazla ilişkili müşteri değerinin kalite itibarı faktörü olduğu saptanmıştır $(r=, 571 ; p=, 000<, 05)$. Marka sadakati ile en fazla ilişkili müşteri değeri faktörünün kalite itibarı faktörü olduğu tespit edilmiştir $(r=, 545$; $p=, 000<, 05)$. Parasal değer ile marka sadakati arasında pozitif yönlü fakat düşük bir ilişki bulunmaktadır $(r=, 282 ; p=, 000<, 05)$. 
Tablo 5: Faktörlere İlişkin Korelasyon Tablosu

\begin{tabular}{|c|c|c|c|c|c|c|}
\hline & $\begin{array}{l}\text { Kalite } \\
\text { itibarı }\end{array}$ & $\begin{array}{l}\text { Parasal } \\
\text { değer }\end{array}$ & Prestij & $\begin{array}{l}\text { Müşteri } \\
\text { değeri }\end{array}$ & $\begin{array}{l}\text { Müşteri } \\
\text { tatmini }\end{array}$ & $\begin{array}{l}\text { Marka } \\
\text { sadakati }\end{array}$ \\
\hline Kalite itibarı & 1 & & & & & \\
\hline Parasal değer & $\begin{array}{l}273 \\
, 000\end{array}$ & 1 & & & & \\
\hline Prestij & $\begin{array}{l}, 362 \\
, 000 \\
\end{array}$ & $\begin{array}{l}, 172 \\
, 005\end{array}$ & 1 & & & \\
\hline Müşteri değeri & $\begin{array}{l}\text {,854 } \\
, 000\end{array}$ & $\begin{array}{l}, 594 \\
, 000\end{array}$ & $\begin{array}{l}\text {,674 } \\
, 000\end{array}$ & 1 & & \\
\hline $\begin{array}{l}\text { Müşteri } \\
\text { tatmini }\end{array}$ & $\begin{array}{l}, 571 \\
, 000\end{array}$ & $\begin{array}{l}, 460 \\
, 000\end{array}$ & $\begin{array}{l}, 471 \\
, 000\end{array}$ & $\begin{array}{l}\text {,698 } \\
, 000\end{array}$ & 1 & \\
\hline $\begin{array}{l}\text { Marka } \\
\text { sadakati }\end{array}$ & $\begin{array}{l}, 545 \\
, 000\end{array}$ & $\begin{array}{l}\text {,282 } \\
, 000\end{array}$ & $\begin{array}{l}\text {,347 } \\
\text {,000 }\end{array}$ & $\begin{array}{l}, 567 \\
, 000\end{array}$ & $\begin{array}{l}, 672 \\
, 000\end{array}$ & 1 \\
\hline
\end{tabular}

Tablo 6'da müşteri değerinin müşteri tatmini üzerindeki etkisini belirlemek üzere yapılan regresyon analizi istatistiksel olarak anlamlı bulunmuştur ( $F=244,664$; $p=, 000<, 05)$. Modele göre müşteri değeri müşteri tatmini üzerindeki varyansın $\% 48,5$ 'ini açıklamaktadır. Müşteri tatmini marka sadakati düzeyini artırmaktadır $(ß=, 698)$

Tablo 6: Müşteri Değeri ile Müşteri Tatminine İlişkin Regresyon Analizi

\begin{tabular}{|l|l|l|l|l|c|}
\hline \multirow{2}{*}{ Model } & \multicolumn{2}{|l|}{ Standardize edilmemiş katsayılar } & $\begin{array}{l}\text { Standardize } \\
\text { katsayılar }\end{array}$ & \multirow{2}{*}{ Sig. } \\
\cline { 2 - 4 } & \multicolumn{2}{|c|}{ Beta } & Std.. Hata & Beta & \\
\hline $\begin{array}{l}\text { (Sabit) } \\
\text { Müşteri } \\
\text { tatmini }\end{array}$ &, 196 &, 163 &, 698 & 1,204 &, 230 \\
\hline $\begin{array}{l}\text { Bağımlı değişken: Müşteri tatmini } \\
\mathrm{r}^{2}=, 487, \text { Düzeltilmiş } \mathrm{r}^{2}=, 485, \mathrm{~F}=244,664\end{array}$ & & 15,642 &, 000 \\
\hline
\end{tabular}

Tablo 7'de müşteri değerini belirleyen faktörlerin müşteri tatmini üzerindeki etkisini belirlemek üzere yapılan regresyon analizi istatistiksel olarak anlamlı bulunmuştur $(F=82,049 ; p=, 000<, 05)$. Modele göre müşteri değeri faktörleri, müşteri tatmini üzerindeki varyansın \%48,4'ünü açıklamaktadır. Kalite itibarı $(ß=, 388)$, parasal değer $(ß=, 305)$ ve prestij $(ß=, 278)$ müşteri tatmini düzeyini arttırmaktadır. Müşteri tatmini üzerinde en fazla etkiye sahip olan değişkenler sırasıyla; kalite itibarı, parasal değer ve prestij faktörleridir.

Tablo 7: Müşteri Değeri ile Müşteri Tatmini Arasındaki Çoklu Regresyon Analizi

\begin{tabular}{|l|c|c|c|c|c|}
\hline \multirow{2}{*}{ Değişkenler } & \multicolumn{2}{|c|}{ Standardize edilmemiş katsayılar } & $\begin{array}{c}\text { Standardize } \\
\text { katsayılar }\end{array}$ & \multirow{2}{*}{ Sig. } \\
\cline { 2 - 4 } & Beta & Std. Hata & Beta & & \\
\hline (Sabit) &, 081 &, 186 & &, 438 &, 662 \\
Kalite itibarı &, 367 &, 047 &, 388 & 7,893 &, 000 \\
Parasal değer &, 297 &, 045 &, 305 & 6,561 &, 000 \\
Prestij &, 251 &, 043 &, 278 & 5,782 &, 000 \\
\hline Bağımlı değişken: Müşteri tatmini & & & \\
r $^{2}=, 49$, Düzeltilmiş $\mathrm{r}^{2}=, 484, \mathrm{~F}=82,049$ &
\end{tabular}

Tablo 8'de müşteri değerini belirleyen faktörlerin marka sadakati üzerindeki etkisini belirlemek üzere yapılan regresyon analizi istatistiksel olarak anlamlı bulunmuştur $(F=43,712 ; p=, 000<, 05)$. Modele göre müşteri değeri faktörleri, marka sadakati üzerindeki varyansın \%32,7'sini açıklamaktadır. Kalite itibarı $(B=, 446)$, parasal değer $(\beta=, 122)$ ve prestij $(\beta=, 169)$ marka sadakati düzeyini arttırmaktadır. Marka 
sadakati üzerinde en fazla etkiye sahip olan değişkenler sırasıyla; kalite itibarı, prestij ve parasal değer faktörleridir.

Tablo 8: Müşteri Değeri Marka Sadakati Arasındaki Çoklu Regresyon Analizi

\begin{tabular}{|l|c|c|c|c|c|}
\hline \multirow{2}{*}{ Değişkenler } & \multicolumn{2}{|l|}{ Standardize edilmemiş katsayılar } & $\begin{array}{l}\text { Standardize } \\
\text { katsayılar }\end{array}$ & \multirow{2}{*}{ Sig. } \\
\cline { 2 - 4 } & Beta & Std. Hata & Beta & & \\
\hline (Sabit) &,- 154 &, 227 & &,- 676 &, 500 \\
Kalite itibarı &, 462 &, 058 &, 446 & 8,017 &, 000 \\
Parasal değer &, 129 &, 056 &, 122 & 2,314 &, 021 \\
Prestij &, 168 &, 054 &, 169 & 3,114 &, 002 \\
\hline Bağımlı değişken: Marka sadakati & & & \\
$\mathrm{r}^{2}=, 334$, Düzeltilmiş $\mathrm{r}^{2}=, 327, \mathrm{~F}=43.712$ &
\end{tabular}

Tablo 9'da müşteri tatmininin marka sadakati üzerindeki etkisini belirlemek üzere yapılan regresyon analizi istatistiksel olarak anlamlı bulunmuştur ( $F=215,125$; $p=, 000<, 05$ ). Modele göre müşteri tatmini marka sadakati üzerindeki varyansın $\% 45$ 'ini açıklamaktadır. Müşteri tatmini marka sadakati düzeyini artırmaktadır $(ß=, 672)$

Tablo 9: Müşteri Tatmini ile Marka Sadakatine İlişkin Regresyon Analizi

\begin{tabular}{|l|c|c|c|c|c|}
\hline \multirow{2}{*}{ Model } & \multicolumn{2}{|l|}{ Standardize edilmemiş katsayılar } & $\begin{array}{l}\text { Standardize } \\
\text { katsayılar }\end{array}$ & \multirow{2}{*}{ Sig. } \\
\cline { 2 - 4 } & Beta & Std. Hata & Beta & & \\
\hline (Sabit) &,- 148 &, 144 & & $-1,034$ &, 302 \\
Müşteri tatmini &, 745 &, 051 &, 672 & 14,667 &, 000 \\
\hline Bağımlı değişken: Marka sadakati \\
$\mathrm{r}^{2}=, 452$, Düzeltilmiş $\mathrm{r}^{2}=, 45, \mathrm{~F}=215,125$ \\
\hline
\end{tabular}

Tablo 10'da araştırma sonuçlarına göre alanyazını destekleyen şekilde müşteri değerinin müşteri tatmini üzerinde etkisinin olduğu tespit edilmiştir. Sonraki aşamada müşteri tatmini ile marka sadakati üzerinde güçlü bir etkisi bulunmaktadır.

Tablo 10: Araştırma Sonuçları (Regresyon Analizi)

\begin{tabular}{|l|l|l|l|}
\hline & Beta & $p$ & Kabul/ Red \\
\hline H1= Müşteri değeri müşteri tatminini pozitif yönde etkilemektedir &, 698 &, 000 & Kabul \\
\hline H2a= Kalite itibarı müşteri tatminini pozitif yönde etkilemektedir &, 388 &, 000 & Kabul \\
\hline H2b= Parasal değer müşteri tatminini pozitif yönde etkilemektedir &, 305 &, 000 & Kabul \\
\hline H2c= Prestij müşteri tatminini pozitif yönde etkilemektedir &, 278 &, 000 & Kabul \\
\hline H3a= Kalite itibarı marka sadakatini pozitif yönde etkilemektedir &, 446 &, 000 & Kabul \\
\hline H3b= Parasal değer marka sadakatini pozitif yönde etkilemektedir &, 122 &, 021 & Kabul \\
\hline H3c= Prestij marka sadakatini pozitif yönde etkilemektedir &, 169 &, 002 & Kabul \\
\hline H4= Müşteri tatmini marka sadakatini pozitif yönde etkilemektedir &, 672 &, 000 & Kabul \\
\hline
\end{tabular}

\section{Sonuç ve Tartışma}

Günümüzde değişen müşteri arzu ve istekleri ile birlikte konaklama işletmelerinin işlevi, müşterilerin konaklama ve yeme içme intiyaçlarının karşılanmasının ötesinde müşteri odaklı hizmet anlayışı ile müşterilerin algılarının değerlendirilmesi, beklentilerinin karşılanması, katlandıkları maliyetlerin (zaman, para, enerji, çaba vd.) üzerinde fayda sağlanmasıdır. Müşterileri için değer oluşturan konaklama işletmeleri, müşterilerin sonraki satın alma davranışlarını doğrudan etkilemekte ve onların tutumlarını ve davranışlarını yönlendirmektedir. 
Araştırmada öncelikle müşteri değeri ve müşteri değerini oluşturan alt faktörlerin müşteri tatmini ve marka sadakati üzerindeki etkisi incelenmiştir. Sonraki aşamada ise müşteri tatmininin marka sadakati üzerindeki etkisi değerlendirilmiştir. Araştırma sonuçlarına göre, müşteri değeri ile müşteri tatmini arasında pozitif bir ilişki tespit edilmiştir. Alanyazın çalışmalarında, müşteri değerinin müşteri tatmini üzerinde pozitif ve doğrudan etkisinin olduğu tespit edilmiştir (Wang ve arkadaşları 2004).

Müşteri değerinin marka sadakati üzerinde pozitif ve doğrudan etkisinin olduğu tespit edilmiştir. Alanyazın çalışmalarında, müşteri değerinin marka sadakati üzerindeki etkisini değerlendiren çalışmalar (Neal, 1999; Sirdeshmukh ve arkadaşları, 2002:28; Huang ve Zhang, 2008:106; Özer ve arkadaşları 2013) bulunmaktadır.

Müşteri tatmininin marka sadakati üzerinde pozitif ve doğrudan etkisinin olduğu tespit edilmiştir. Alanyazın çalışmalarında, müşteri tatmininin marka sadakati üzerinde pozitif ve doğrudan etkisinin olduğu saptanmıştır (Cronin ve arkadaşları 2000; Kandampully ve Suhartanto 2000; Cronin ve Taylor 1992; McAlexander ve arkadaşları 1994; Back ve Parks 2003; Rust ve Zahorik 1993; McDougall ve Levesque 1994).

Alanyazın çalışmalarında, müşteri değerinin müşterinin aracılık rolü ile marka sadakati üzerindeki etkisini değerlendiren çalışmalara rastlanmıştır. Onaran ve arkadaşlarının (2013) yaptıkları araştırmada müşteri tatminin marka sadakati üzerinde yüksek düzeyde etkisi olduğu ve bu etkinin önemli bir kısmının da müşteri tatmininin dolaylı etkisiyle ortaya çıktığı belirlenmiştir. Uzkurt'un (2007) hizmet sektöründeki araştırmasında, müşteri değerinin müşteri tatmini yoluyla satın alma sonrası eğilimler üzerinde dolaylı ve güçlü etkiye sahip olduğu tespit edilmiştir.

Araştırma bulgularına göre, üniversite sosyal tesislerini tercih eden müşterilerin, müşteri tatminine yönelik değer unsurları öncelik sıralaması; kalite itibarı, parasal değer ve prestij olarak değerlendirilmiştir. Müşterilerin marka sadakatine yönelik değer unsurları öncelik sıralaması ise; kalite itibarı, prestij ve parasal değer olarak değerlendirilmiştir. Kalite itibarının müşteri tatmini ve marka sadakati üzerinde en fazla etkiye sahip olan müşteri değeri faktörü olduğu tespit edilmiştir. Kalite itibarı, müşterilerin beklentilerinin karşılanmasında ve işletmenin ürün ve hizmetlerini tekrar eden davranışla/tutumla satın almalarındaki en önemli kriterdir.

Araştırma üniversitenin sosyal tesislerinde gerçekleştirilmiştir. Gelecekte yapılacak araştırmalar farklı sınıflardaki konaklama işletmelerinde gerçekleştirilebilir. Araştırmada müşteri değeri müşteri boyutu ile değerlendirilmiştir. Gelecekte yapılacak araştırmalarda müşteri değeri işletme boyutu ile değerlendirilebilir.

\subsection{Yöneticilere Öneriler}

Gün geçtikçe artan turist sayıları/turizm gelirleri ile birlikte, yeni işletmeler farklı fiziksel özellikler ile turizm pazarına yatırım yapmaktadır. Yeni yatırımlar ise bölgesel, ulusal ve uluslararası düzeyde işletmeler arasında rekabetin artmasına yol açmaktadır. Bu çerçevede yöneticilerin işletmelerin üstün rekabet elde etmelerine yönelik geleneksel yöntemleri uygulamaları yerine yenilikçi yöntemler geliştirmeleri ve rakip işletmeler karşısında müşteri odaklı stratejiler ile rekabet üstünlüğü elde etmeye çalışmaları gerekmektedir.

Yöneticilerin, müşteri değeri ile müşterilerin ürün ve hizmetleri elde etmek için katlandıkları maliyetlerin üzerinde fayda sağlamaları gerekmektedir. Özellikle müşterileri tarafından tercih edilen unsurların (kalite itibarı, parasal değer, prestij) 
öncelik sıralamasını tespit etmeleri ve öncelikli değer unsurlarına yönelik stratejiler geliştirmeleri işletmeye rekabetçi üstünlük sağlayacaktır.

Turizm sektörü/turizm işletmesi için değer, tek bir değer unsuru yerine müşteriler tarafından algılanan bütün değer unsurlarının birleşiminden oluşmaktadır. Bu çerçevede turizm işletmelerinin (konaklama işletmesi, seyahat işletmesi, yiyecek içecek işletmesi vd.) müşteri değeri oluşturmaya yönelik 'ortaklaşa rekabet' ${ }^{2}$ etmesi önemlidir. Turizm işletmelerinin müşterilerine katma değer sağlamaları, sahip oldukları üstün kaynakları/yetenekleri ile ortaklaşa hareket etmeleri ile mümkündür.

\section{Kaynakça}

Aaker, D.A. (1991), Managing Brand Equity, Free Press, New York, NY.

Akman, E. (2016), 'The Facilitating Role of Visa Policies on International Trade and Foreign Direct Investment', Turkish Studies, 17(4), ss. 712-732.

Arora, R. ve Singer, J. (2006), 'Customer Satisfaction and Value as Drivers of Business Success for Fine Dining Restaurants', Services Marketing Quarterly, 28(1), ss. 89-102.

Back, K. J., ve Parks, S. C. (2003), 'A Brand Loyalty Model Involving Cognitive, Affective, and Conative Brand Loyalty and Customer Satisfaction', Journal of Hospitality \& Tourism Research, 27(4), ss. 419-435.

Ballester, E. D., Aleman, J. L. M. (2005), 'Does Brand Trust Matter to Brand Equity?', The Journal of Product \& Brand Management, 14 (2/2). ss.187-196.

Bitner, M. J. (1990), 'Evaluating Service Encounters: The Effect of Physical Surroundings and Employee Responses', Journal of Marketing, 54, ss. 69-82.

Bowen, John T. ve Chen S.L. (2001), 'The Relationship Between Customer Loyalty and Customer Satisfaction', International Journal of Contemporary Hospitality Management, Cilt: 13, Sayı: 5, ss. 213-217.

Cronin J. J. Jr, ve Taylor, S. A. (1992), 'Measuring Service Quality: a Reexamination and Extension' The Journal of Marketing, ss. 55-68.

Cronin, J., Brady, M.K., Hult, T.M.,(2000), 'Assessing the Effects of Quality, Value and Customer Satisfaction on Consumer Behavioral Intentions in Service Environments', Journal of Retailing, 76 (2), ss. 193-218.

De Ruyter, J. K., Wetzels, M., Lemmink, J., Mattson, J. (1997), 'The Dynamics of the Service Delivery Process: A Value-based Approach', International Journal of Research in Marketing, 14, ss. 231-243.

Deng, W. J., Yeh, M. L., Sung, M. L. (2013), 'A Customer Satisfaction Index Model For International Tourist Hotels: Integrating Consumption Emotions into the American Customer Satisfaction Index', International Journal of Hospitality Management, 35, ss. 133-14,

Eggert, A., ve Ulaga, W. (2002), 'Customer Perceived Value: A Substitute For Satisfaction in Business Markets'? Journal of Business \& Industrial Marketing, 17(2/3), ss. 107-118.

Flint, D.J., Woodruff, R.B., Gardial, S.F., (1997), 'Customer Value Change in Industrial Marketing Relationships: A Call For New Strategies And Research' Industrial Marketing Management, 26 (2), ss. 163-175.

Fornell, C., Johnson, M.D., Anderson, E.W., Cha, J., \& Bryant, B.E. (1996), 'The American Customer Satisfaction Index: Nature, Purpose, and Findings' Journal of Marketing, 60(4), ss. 7-18.

\footnotetext{
${ }^{2}$ Aynı sektörde faaliyet gösteren turizm işletmelerinin ortaklaşa rekabet etmesi müşteriler için bir değer unsurudur. Ortaklaşa rekabet, bireysel turistik ürün yerine toplam turistik ürünün müşterilere yansımasıdır.
} 
Gibson, H., (2005), 'Towards an Understanding of 'Why Sport Tourists Do What They Do'. Sport in Society Special Issue: Sport Tourism: Concepts and Theories 8 (2), ss. $198-217$.

Groth, J. C. (1995a), 'Important Factors in the Sale and Pricing of Services' Management Decision, 33(7), ss. 29-34.

Groth, J. C. (1995b), 'Exclusive Value and the Pricing of Services' Management Decision, 33(8), ss. 22-29.

Grönroos, C. (1997), 'Value-Driven Relational Marketing: From Products to Resources and Competencies' Journal of Marketing Management, 13(5), ss. 407-42,

Gu, H., ve Ryan, C., (2008), 'Chinese Clientele at Chinese Hotels: Preferences and Satisfactions' Int. J. Hosp. Manag. 27, ss. 337-345.

Güler, E. G. (2009), 'Otel İşletmelerinde Değer Yaratma ve Müşteri Değeri Algılaması Üzerine Bir Araştırma: Edirne'deki Oteller Örneği' Anatolia: Turizm Araştırmaları Dergisi, 20 (1), ss. 61-76.

Huang, J. ve Zhang, D. (2008), 'Customer Value and Brand Loyalty: Multi-Dimensional Empirical Test', International Seminar on Future Information Technology and Management Engineering, ss. 102-106.

Kalaycı, Ş. (2010), Spss Uygulamalı Çok Değişkenli İstatistik Teknikleri (Vol. 5). Ankara, Turkey: Asil Yayın Dağıtım.

Kandampully, J. ve Suhartanto, D. (2000), 'Customer Loyalty in the Hotel Industry: The Role of Customer Satisfaction and Image' International Journal of Contemporary Hospitality Management, 12 (6), ss. 346-351.

McAlexander, J. H., Kaldenburg, D. O., \& Koenig, H. F. (1994), 'Service Quality Measurement' Marketing Health Services, 14 (3), ss. 34-40.

McDougall, G., ve Levesque, T. (1994), 'A Revised View of Service Quality Dimensions: An Empirical Investigation' Journal of Professional Service Marketing, 11(1), ss. 189-21,

Meyer J.P., ve Allen, N.J. (1997), Commitment In Workplace, Theory, Research and Application, London, Sage Publications.

Nam, J., Ekinci, Y., ve Whyatt, G. (2011), 'Brand Equity, Brand Loyalty and Consumer Satisfaction' Annals of Tourism Research, 38(3), ss. 1009-1030.

Nasution, H. N., ve Mavondo, F. T. (2008), 'Customer Value in the Hotel Industry: What Managers Believe They Deliver and What Customer Experience'. International Journal of Hospitality Management, 27 (2), ss. 204-213.

Neal, V. D. (1999), 'Satisfaction is Nice, But Value Drives Loyalty', Marketing Research, 11 (1), ss. 20-23.

O'Fallon, M. J., ve Rutherford, D. G. (2011), Hotel Management And Operations. John Wiley \& Sons. New Jersey.

Oh, H. (2000), 'The Effect of Brand Class, Brand Awereness, and Price on Customer Value and Behavioral Intentions' Journal of Hospitality \& Tourism Research, 24(2), ss. 136-162.

Oliver, R.L. (1997), Satisfaction: A Behavioral Perspective on the Consumer. McGrawHill, NY.

Onaran, B., Bulut, Z. A., Özmen, A. (2013), 'Müşteri Değerinin, Müşteri Tatmini, Marka Sadakati ve Müşteri İlişkileri Yönetimi Performansı Üzerindeki Etkilerinin Incelenmesine Yönelik Bir Araştırma', Business and Economics Research Journal, 4(2). ss. 37-53.

Özer L., Barul B.G., Gültekin B. (2013), 'Bankacılık Sektöründe Müşteri Değerinin Marka Algıları ve Müşteri Sadakati Çerçevesinde İncelenmesi, Sosyoekonomi, 19 (19), ss. 295-314.

Patterson, P. G., ve Spreng, R. A. (1997), 'Modelling the Relationship between Perceived Value, Satisfaction and Repurchase Intentions in a Business-to- 
Business, Services Context: An Empirical Examination'. International Journal of Service Industry Management, 8(5), ss. 414-434.

Petrick, J. F. (2002), 'Development of a Multi-Dimensional Scale For Measuring The Perceived Value of a Service'. Journal of Leisure Research, 34(2), ss. 119-134.

Reichheld, F.F. (1996), The Loyalty Effect, Harvard Business School Press, Boston, MA.

Ren, L., Qiu, H., Wang, P., Lin, P.M.C. (2016), 'Exploring Customer Experience Withbudget Hotels: Dimensionality and Satisfaction' Int. J. Hosp. Manag. 52, ss. 13-23.

Rodriguez Del Bosque, I., \& San Martin, H. (2008), 'Tourist Satisfaction a CognitiveAffective Model'. Annals of Tourism Research, 35 (2), ss. 551-573.

Rust, R. T., ve Zahorik, A. J. (1993), 'Customer Satisfaction, Customer Retention, and Market Share' Journal of Retailing, 69 (2), ss. 193-215.

Sanchez, J., Callarisa, L., Rodriguez, R.M., Moliner, M.A. (2005), 'Perceived Value of the Purchase of a Tourism Product' Tourism Management, 27 (3), ss. 394-409.

Sheth, J. N., Newman, B. I., Gross, L. G. (1991a), Consumption Values and Market Choice. Cincinnati, $\mathrm{OH}$ : Shouth Western Publishing.

Sheth, J. N., Newman, B. I., Gross, L. G. (1991b), 'Why We Buy What We Buy: A Theory of Consumption Values' Journal of Business Research, 22, ss. 159-17,

Shoemaker, S. ve Lewis, R. C. (1999), 'Customer Loyalty: The Future of Hospitality Marketing' International Journal of Hospitality Management, 18, ss. 345-37,

Sirdeshmukh, D. Singh, J. Sabol, B. (2002), 'Consumer Trust, Value and Loyalty in Relational Exchanges', Journal of Marketing, 66 (Jan.), ss. 15-37.

Slater, S.F., ve Narver, J.C. (2000), 'Intelligence Generation and Superior Customer Value' Journal of Academy of Marketing Science, 28(1), ss. 120-127.

Sweeney, J. C., ve Soutar, G. (2001), 'Consumer Perceived Value: The Development of Multiple Item Scale' Journal of Retailing, 77(2), ss. 203-220.

Sweeney, J. C., Soutar, G. N., Johnson, L. W. (1999), 'The Role of Perceived Risk in the Quality-Value Relationship: A Study in a Retail Environment' Journal of Retailing, 75(1), ss. 77-105.

Tepeci, M. (1999), 'Increasing Brand Loyalty in the Hospitality Industry' International Journal of Contemporary Hospitality Management, 11(5), ss. 223-230.

Unwto. (2016). Tourism Highlights, 2016 Edition, UNWTO. http://www.eunwto.org/doi/pdf/1,18111/9789284418145. Erişim Tarihi: 23 Kasım 2016.

Uzkurt, C. (2007, 'Müşteri Değeri ve Tatmininin Satın Alım Sonrası Gelecek Eğilimlere Etkisi Üzerine Ampirik Bir Çalışma' Dumlupınar Üniversitesi Sosyal Bilimler Dergisi, 17, ss. 25-43.

Wang, Y., Lo, H.P., Chi, R., Yang, Y. (2004), 'An Integrated Framework for Customer Value and Customer-Relationship-Management Performance: A CustomerBased Perspective from China' Managing Service Quality,14(2/3), ss. 169-182.

Woodruff, R.B. (1997), 'Customer Value: The Next Source for Competitive Advantage', Journal of the Academy of Marketing Science, Vol. 25, ss. 139-153.

World Travel \& Tourism Council. '2016 Report of the Travel and Tourism Economic Impact Turkey.', http://www.wttc.org/-

/media/files/reports/economic\%20impact\%20research/countries\%202016/turkey 2016.pdf, Erişim Tarihi: 23 Kasım 2016.

Yamamato, G. T. (2007). 'Understanding Customer Value Concept: Key To Success', www.opf.slu.cz/vvr/akce/turecko/pdf/Yamamoto.pdf, , ss. 547-552, Erişim tarihi: 01.06.2016.

Zeithaml, V.A., (1988), 'Consumer Perceptions of Price, Quality, and Value: A MeansEnd Model and Synthesis of Evidence' Journal of Marketing 52 (3). ss. 2-22. 